\section{Tight jeans as a compression garment after major trauma}

The $g$ suit (military antishock trousers) has been described in the management of severe pelvic and abdominal injuries. A similar function may be performed by tight fitting garments, and their role in the management of patients with severe injuries may be very important.

\section{Case report}

A 22 year old man sustained a severe compression injury to his lower abdomen and pelvis in a road traffic accident. On admission he was wearing tight fitting jeans with a $7.5 \mathrm{~cm}$ broad leather belt. He was not shocked and complained of pain in his lower abdomen and left hip. His condition remained stable for 25 minutes until his jeans, which were too tight to remove, were cut off. The leg was seen visibly to expand, his abdomen distended, and he collapsed with an unrecordable blood pressure. Rapid resuscitation with 31 of fluid returned his blood pressure to $90 / 60 \mathrm{~mm} \mathrm{Hg}$

Examination showed a distended abdomen, an externally rotated left leg, and an extremely swollen left thigh. Bowel sounds were present but the abdomen was extremely tender. Rectal examination disclosed a normal prostate. Clinically the patient had a fractured pelvis, and this was confirmed radiologically (figure). There were no other apparent injuries.

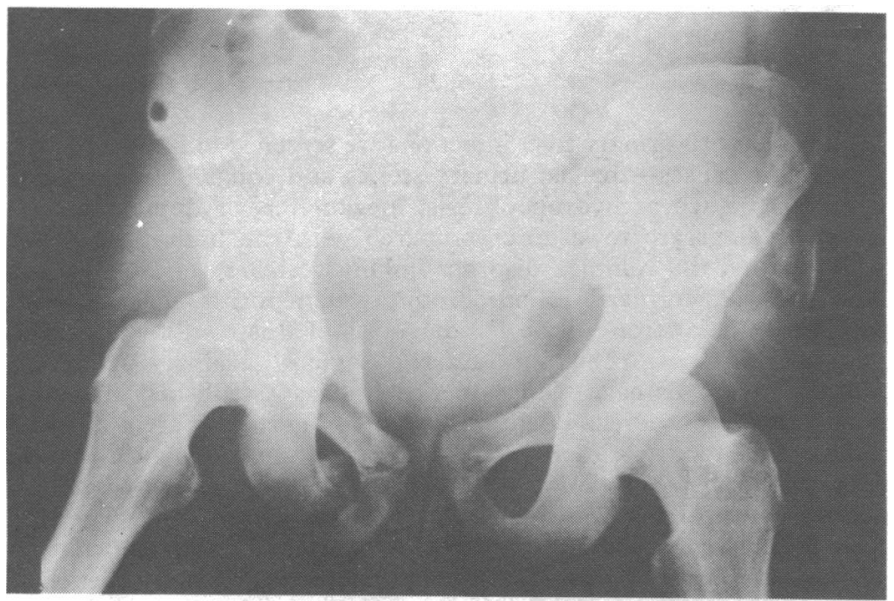

$X$ ray appearance of pelvis on admission. (Anteroposterior view.)

After resuscitation laparotomy was performed. The urethra was intact and a catheter passed easily into the bladder. In the peritoneal cavity there was a large quantity of free blood and small bowel contents with an extensive retroperitoneal haematoma arising from the pelvis. There were five perforations of the ileum and two defects in the mesentery. The descending colon was damaged and dubiously viable. All the bowel defects were repaired, the bleeding vessels ligated, and the descending colon resected to produce an end transverse colostomy and a mucous fistula. The retroperitoneal haematoma was not explored and did not change during the operation. The pelvic fracture was treated initially with a sling followed by external fixation and traction for eight weeks. The transverse colon was joined to the sigmoid at 10 weeks. The patient was discharged at 12 weeks, walking and with normal bowel, urine, and sexual functions.

\section{Comment}

The complications of pelvic fractures-namely, damage to the urethra, rectum, nerves, and vessels-are well recognised. ${ }^{\prime}$ It is standard practice when admitting severely injured patients fully to undress them so that a proper and thorough examination may be carried out. The magnitude of blood lost in closed injuries has been reported, and there have been several studies on the use of the $g$ suit in an attempt to limit haemorrhage and maintain blood pressure. ${ }^{2} 3$ Crile in 1903 described the use of external counterpressure by means of a pneumatic suit to control blood pressure, and clinical use of the $g$ suit, or MAST (military antishock trousers), was first described in Vietnam $^{2}$ in 1971 and then in civilian use in Miami in $1973 .^{3}$ The garment works $(a)$ by limiting blood loss, and $(b)$ by preventing venous pooling.

Rapid deflation of the $g$ suit may produce shock, ${ }^{45}$ and the condition of our patient apparently remained stable until his jeans, which were acting as a compression garment, were removed. McSwain advised slow deflation of the suit, ${ }^{4}$ and Pelligra and Sandberg warned against removal of the suit before there had been adequate fluid replacement. ${ }^{5}$ In our patient fluid replacement should have been started before removing his jeans.

This case serves as a caution, as clearly there may be similar patients with major injuries to the legs and pelvis where removal of tight garments may be counterproductive before instituting fluid or blood replacement.

' Patterson FP, Morton KS. The cause of death in fractures of the pelvis. F Trauma 1973;13:849.

2Cutler BS, Daggett WM. Application of the "G-suit" to the control of hemorrhage in massive trauma. Ann Surg 1971;173:511-4.

${ }^{3}$ Kaplan BC, Civetta JM, Nagel EL, Nussenfeld SR, Hirschman JC. The military anti-shock trouser in civilian pre-hospital emergency care. 7 Trauma 1973;13:843-8.

$M c$ Swain NE. Pneumatic trousers and the management of shock. $f$ Trauma 1977;17:719-24.

${ }^{5}$ Pelligra R, Sandberg EC. Control of intractable abdominal bleeding by external counter-pressure. $\mathcal{F} A M A 1979 ; 241: 708-13$.

(Accepted 12 December 1983)

Westminster Hospital, London SW1P 2AP

JOHN H SCURR, BSC, FRCS, senior surgical registrar

PAULINE CUTTING, MB, FRCS, registrar

Correspondence to: $\mathrm{Mr}$ John $\mathrm{H}$ Scurr.

\section{Side effects of disodium aminohydroxypropylidenediphos- phonate (APD) during treatment of bone diseases}

The drug (3-amino-1-hydroxypropylidene)-1,1-diphosphonate (disodium aminohydroxypropylidenediphosphonate; APD) is effective in patients with Paget's disease of bone ${ }^{3}{ }^{3}$ and those with hypercalcaemia due to malignant diseases. ${ }^{4}$ Cortical bone mass has been found to increase during treatment with APD. ${ }^{5}$ We therefore thought it important to assess the extraskeletal side effects of long term treatment with the drug.

\section{Patients, methods, and results}

Over three years we administered APD to 169 patients, of whom 138 had Paget's disease of bone, 28 primary osteoporosis, two breast carcinoma with bone metastasis, and one primary hyperparathyroidism. APD was taken by mouth in tablets of $100 \mathrm{mg}$. The daily dose ranged from 6.0 to $8.2 \mathrm{mg} / \mathrm{kg}$ body weight. The mean duration of treatment was 8.5 months (making a total of 119.7 patient years), and the mean duration of clinical observation after the start of treatment was 14.7 months (total 207.0 patient years).

During treatment with APD eight patients $(4.7 \%)$ developed gastric intolerance that interrupted treatment; six $(3.6 \%)$ developed minor gastrointestinal disturbances; and two $(1 \cdot 2 \%)$ developed rashes. One patient with Paget's disease of bone developed thrombocytopenic purpura one month after the start of treatment with APD; during the following 14 months this patient required continuous treatment with prednisone (about $20 \mathrm{mg}$ day) to maintain the platelet count above $100 \times 10^{9} / 1$. Chronic idiopathic thrombocytopenic purpura was diagnosed because of the prolonged clinical evolution of the symptoms. Although unlikely, sensitivity to APD cannot be completely excluded as it is not known for how long the drug stored in the skeleton can be released into the blood. Platelet and red cell counts were in the normal range throughout treatment in all patients except the one who developed thrombocytopenic purpura.

Periodic haematological examination in 142 patients showed mild leucopenia $\left(3-4 \times 10^{9} / 1\right)$ in $11(7 \cdot 7 \%)$. The differential counts were within the normal range, and absolute granulocytopenia $\left(<2 \times 10^{9} / 1\right)$ was observed in six patients $(4 \cdot 2 \%)$. None of the 11 patients, who had either Paget's disease of bone or primary osteoporosis, had had leucopenia or granulocytopenia on examination before the start of treatment with APD. White cell counts returned to normal when treatment was interrupted or the dose decreased.

\section{Comment}

In our experience prolonged treatment with APD does not have any important clinical side effects. We are currently studying the 
BRITISH MEDICAL JOURNAL VOLUME $288 \quad 17$ MARCH 1984

nature of the minor asymptomatic leucopenia found in some patients. In the meantime frequent counts of white cells should be performed in patients receiving APD.

\section{APD was supplied by Laboratorios Dr Gador.}

' Frijlink WB, Te Velde J, Bijvoet OL, Heynen G. Treatment of Paget's disease with (3-amino-1-hydroxypropylidene)-1,1-bisphosphonate (APD). Lancet 1979; :799-803.

2 Nagant de Deuxchaisnes C, Rombouts-Lindemans C, Huaux JP, et al. Treatment of Paget's disease with the diphosphonate APD. A biological and radiological study. In: Donath A, Courvoisier B, eds. Diphosphonates and bone. Geneva: Medicine et Hygiene, 1982:303-27.

${ }^{3}$ Fromm GA, Plantalech L, Casco C, Gonzalez D, Mautalen CA. 3-amino1-hydroxypropylidene-1,1-bisphosphonate (APD) in the treatment of patients with Paget's bone disease. Medicina (B Aires) (in press).

4 Van Breukelen FJM, Bijvoet OL, Van Oosterom AT. Inhibition of osteolytic bone lesions by (3-amino-1-hydroxypropylidene)-1,1-bisphosphonate (APD). Lancet 1979 ;i :803-5.

${ }^{5}$ de Deuxchaisnes CN, Devogelaer JP, Esselinchx W, Depresseux G, Rombouts-Lindemans C, Huaux JP. Non-hormonal treatment of osteoporosis. Br Med J 1983;286:1648.

(Accepted 1 December 1983)

\section{Centro de Osteopatías Médicas, Buenos Aires, Argentina}

C A MAUTALEN, MD, consultant physician

C A CASCO, PHD, biochemist

D GONZALEZ, MD, research fellow

Department of Endocrinology, Hospital de Clinicas, Buenos Aires G R GHIRINGHELLI, MD, consultant physician

C MASSIRONI, MD, house officer

Department of Endocrinology, Hospital Italiano, Bụenos Aires

G A FROMM, MD, consultant physician

L PLANTALECH, MD, house officer

Correspondence to: Dr C A Mautalen, Saavedra 189, 1083 Buenos Aires, Argentina.

\section{Laser irradiation of tumours of the oesophagus and gastric cardia}

A recent report from a London group indicated that tissue vaporisation by laser irradiation might offer reasonable palliation in cases of partial obstruction of the trachea or main bronchus due to bronchial carcinoma. ${ }^{\prime}$ We have used the technique to maintain luminal patency in tumours of the oesophagus and gastric cardia.

\section{Patients, method, and results}

To date, nine patients with a mean age of 78.6 years have been treated (see table). None was deemed suitable for surgical resection. A squamous cell carcinoma was discovered coincidentally in a patient with oesophageal varices (case 5), but in the remainder dysphagia was the main presenting symptom and endoscopy showed extensive obstruction of the oesophageal lumen.

The instrument used was the Molectron 8000 Neodymium YAG laser, set to deliver about 100 watts through a $600 \mu \mathrm{m}$ quartz fibre at pulses of $0.5-1.0$ second. An aiming light is provided by a separate xenon source. The laser fibre is passed through the biopsy channel of a standard panendoscope fitted with a protective filter. Patients were sedated with 5-20 mg diazepam intravenously during the procedure. The mean energy applied was 2950 Joules (range 468-6390 Joules) and patients received on average three laser treatments at intervals of two to four weeks. Provided that their general condition allowed, they were discharged home after about four days.

The table outlines the progress of the nine patients after treatment. In every case after application of the laser the patient was able to eat solid food. One patient (case 8) had previously been managed with an Atkinson tube for 18 weeks. During a holiday visit a food bolus had obstructed the tube, which was removed. Within 10 days there was complete blockage of the oesophagus, and it was only after the third laser treatment that a further tube could be inserted. In case 3 the patient originally underwent surgery for an apparently benign leiomyoma at the cardia. The lesion recurred and he required repeated transfusions. Over six months laser applications effectively reduced both tumour bulk and transfusion requirements. Later he underwent a further, successful operation, and histological examination showed a malignant leiomyosarcoma. At the time of reporting, the mean survival after first application of the laser was 15.8 weeks (range 3-39 weeks)

Complications-A 76 year old woman (case 2) presented with a $90 \%$ luminal obstruction, and after eight sessions of laser irradiation over 24 weeks an unsuccessful attempt was made to insert an Atkinson tube; this resulted in oesophageal perforation, and she died some days later. A 91 year old woman (case 7) died directly as a result of laser treatment. An initial treatment improved her ability to swallow but three weeks later the tumour, once again obstructing, was treated with the laser. Within two hours she complained of retrosternal discomfort, and oesophageal perforation (subsequently shown to be due to the laser) resulted in her death three days later.

\section{Comment}

The object of palliation is to improve the quality of remaining life, with the knowledge that improving the nutritional state of the patient may also have a positive effect on survival. Atkinson and his colleagues demonstrated the value of endoscopic intubation, ${ }^{2}$ and this procedure is now firmly established in the palliation of oesophagogastric tumours. Some cases, however, may not be amenable to the technique.

Our series shows that even in advanced malignancy luminal patency can be maintained, albeit by repeated laser application, with little or no dietary restriction for the patient. The procedure was well tolerated and, although our patients were kept in hospital for four or five days after treatment, an overnight stay may be all that is required. Laser treatment and endoscopic intubation may be complementary rather than alternative procedures, although the experience in our case 2 indicates that careful thought must be given to the relative timing of the two techniques. We conclude that laser treatment is practicable and associated with good patient tolerance but that at present it should be considered only in terms of palliation, and it does not compete where radical surgical treatment is possible.

We are pleased to acknowledge the ready and enthusiastic help of Sister E C Smith and her staff on the gastrointestinal unit, and also the forbearance of the endoscopy theatre nurses during the early and difficult stages of the study.

${ }^{1}$ Hetzel MR, Millard FJC, Ayesh R, et al. Laser treatment for carcinoma of the bronchus. Br Med $\mathcal{F} 1983 ; 286: 12-6$.

2 Ogilvie AL, Dronfield $M W$, Ferguson R, Atkinson M. Palliative intubation of oesophagogastric neoplasms at fibreoptic endoscopy. Gut $1982 ; 23$ : 1060-7.

(Accepted 23 November 1983)

Gastrointestinal Unit, Walton Hospital, Liverpool L9 1AE

NEVILLE KRASNER, MD, FRCPGLAS, consultant physician and gastroenterologist

JUDY BEARD, MB, CHB, senior medical house officer

Correspondence to: Dr Neville Krasner.

Presentation and outcome in nine patients with gastro-oesophageal tumours after laser treatment

\begin{tabular}{|c|c|c|c|c|c|c|c|}
\hline $\begin{array}{l}\text { Case } \\
\text { No }\end{array}$ & $\underset{\text { (years) }}{\text { Sex and age }}$ & Tumour site & Histological findings & $\begin{array}{c}\text { Laser } \\
\text { applications }\end{array}$ & $\begin{array}{c}\text { Time scale } \\
\text { (weeks) }\end{array}$ & $\begin{array}{c}\text { Survival } \\
\text { (weeks) }\end{array}$ & Subsequent progress \\
\hline $\begin{array}{l}1 \\
2 \\
3 \\
4 \\
5 \\
6 \\
7 \\
8 \\
9\end{array}$ & $\begin{array}{ll}F & 77 \\
F & 76 \\
M & 76 \\
M & 82 \\
F & 65 \\
F & 77 \\
F & 91 \\
F & 85 \\
M & 79\end{array}$ & $\begin{array}{l}\text { Oesophagus } \\
\text { Oesophagus } \\
\text { Cardia } \\
\text { Oesophagus } \\
\text { Oesophagus } \\
\text { Gastro-oesophageal } \\
\text { Oesophagus } \\
\text { Oesophagus } \\
\text { Gastro-oesophageal }\end{array}$ & $\begin{array}{l}\text { Adenocarcinoma } \\
\text { Squamous carcinoma } \\
\text { Leiomyosarcoma } \\
\text { Adenocarcinoma } \\
\text { Squamous carcinoma } \\
\text { Adenocarcinoma } \\
\text { Adenocarcinoma } \\
\text { Adenocarcinoma } \\
\text { Adenocarcinoma }\end{array}$ & $\begin{array}{l}1 \\
8 \\
6 \\
1 \\
2 \\
1 \\
2 \\
3 \\
2\end{array}$ & $\begin{array}{r}0 \\
23 \\
20 \\
0 \\
3 \\
0 \\
3 \\
1 \\
1\end{array}$ & $\begin{array}{l}39 \\
24 \\
28^{*} \\
3 \\
16^{*} \\
16^{*} \\
4 \\
6^{*} \\
6^{*}\end{array}$ & $\begin{array}{l}\text { Died after haematemesis } \\
\text { Perforation after tube insertion } \\
\text { Second attempt at surgical removal } \\
\text { Death from pneumonia } \\
\text { Radiotherapy } \\
\text { Remained well } \\
\text { Perforation by laser } \\
\text { Tube inserted } \\
\text { Remained well }\end{array}$ \\
\hline
\end{tabular}

-Alive. 